\title{
LITHIC TECHNOLOGY STUDIES IN COLOMBIA DURING THE LATE PLEISTOCENE AND EARLY HOLOCENE*
}

\author{
ESTUDIOS DE LA TECNOLOGÍA LÍTICA EN COLOMBIA \\ ENTRE EL PLEISTOCENO FINAL Y EL HOLOCENO TEMPRANO
}

\author{
Francisco Javier Aceituno ${ }^{1}$ and Sneider Rojas-Mora ${ }^{1}$
}

\begin{abstract}
This paper provides an overview of the lithic technology of human groups that inhabited Colombian territory between the Late Pleistocene and the early Holocene. The chosen methodology was to document and compare the lithic technology regionally, in order to show the differences in theoretical and methodological approaches applied.
\end{abstract}

Key words: Colombia, lithic technology, Late Pleistocene, Early Holocene.

En este artículo se presenta una sinopsis de las investigaciones arqueológicas que se refieren a la tecnología lítica de los grupos humanos que poblaron el territorio colombiano entre el Pleistoceno Final y el Holoceno Temprano. Como metodología se ha optado por documentar y comparar regionalmente los análisis de tecnología y así demostrar las diferencias en los enfoques teóricos y metodológicos aplicados en las diferentes investigaciones que se han ocupado del tema.

Palabras claves: Colombia, tecnología lítica, Pleistoceno Final, Holoceno Temprano.

In the earliest periods of Colombian prehistory that roughly coincide with the Late Pleistocene and early Holocene, lithic artifacts compose the majority of the scarce evidence that constitutes the record for this time in human history. Just as in other places, Colombian archaeology has used lithic technology to define cultural periods, suggest subsistence strategies and record regional interactions (Aceituno et al. 2011; Aceituno and Rojas 2012; Castillo and Aceituno 2006; Correal 1986; Gnecco 2000; López 1999; Salgado 1988-1990).

The aim of this paper is to present a synthesis of the studies that have dealt with the lithic technology of the Late Pleistocene and early Holocene. For this we review the most representative case studies and selected those that have more general information data, analysis and broader impact within the discipline in terms of lithic technology studies.

\section{The Earliest Lithic Industries in Northwest South America}

Due to the limited evidence for human occupation during the time period, lithic assemblages have played a major role in archaeological explanations in the region. Questions such as who were the early peoples, which adaptive strategies did they have, where did the come from, among others (Anderson y Gillam 2000; Dillehay 2000; Fiedel 2000; Lynch 1990; Waguespack 2007), have been asked and the explanations so far are deeply connected with the ways that these peoples manipulated lithic resources.

The earliest evidences of human occupation in Colombian archaeology have been found in the Sabana de Bogota and the Middle Basin of the Magdalena River regions. The Sabana de Bogotá, a 2,600 $\mathrm{m}$ asl (Figure 1) high Andean plateau,

\footnotetext{
* This article was originally presented at the "Early Lithic Technologies: Beyond Regional Projectile Point Typologies" Symposium at the 77th SAA Meeting Memphis, Tennessee, April 2012. Guest editors Kurt Rademaker and César Méndez conducted the peer-review process following the Journal's editing policies.

1 Departamento de Antropología, Grupo de Investigación Medio Ambiente y Sociedad, Universidad de Antioquia, AA 1226 Medellín, Colombia.csfjace@antares.udea.edu.co; sneiderrojas@yahoo.com
} 


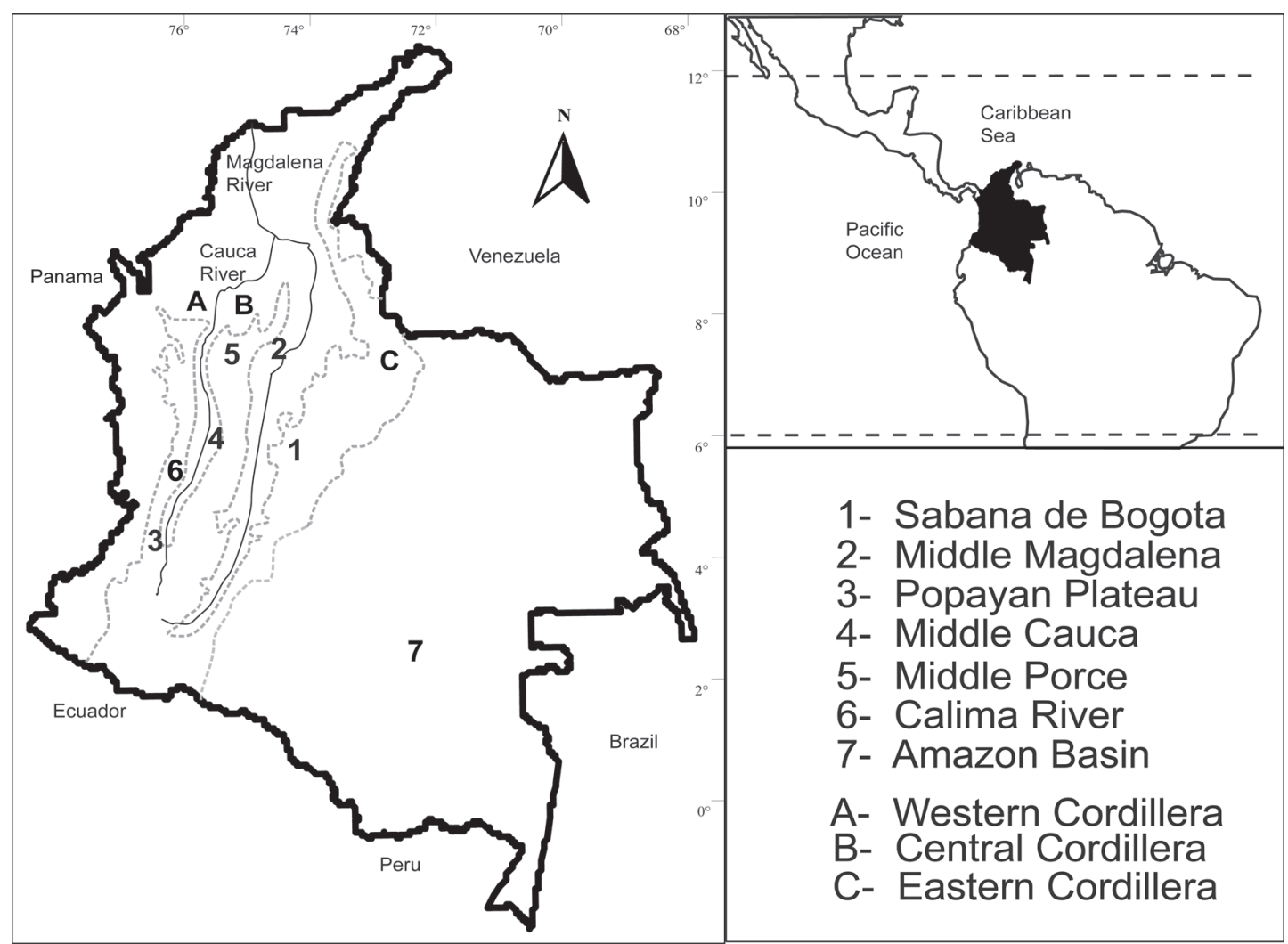

Figure 1. Location archaeological areas cited in the text.

Localización de las regiones arqueológicas citadas en el texto.

was occupied by hunter-gatherers from the Late Pleistocene into the Middle Holocene, showing a great continuity in their material culture. The lithics found throughout this time period has been called the Abriense or edged tool tradition (Correal 1986; Hurt et al. 1972). One of the earliest dates for Colombia comes from the site of El Abra where 37 chert flakes and a Holocene faunal assemblage (i.e., no extinct species) were dated at $12,400 \pm 160 \mathrm{BP}(\mathrm{GrN}-5556)$ [cal BC 13,236:12,121] $]^{1}$ (Correal 1986; Hurt et al. 1972). At the open air butchering site called Tibitó, more Abriense stone tools were recovered associated with faunal remains of mastodon (Haplomastodon sp. and Cuvieronius sp.), American horse (Equus sp.) and deer (Odocoileus virginianus) dated at $11,740 \pm 110 \mathrm{BP}(\mathrm{GrN}-9375)$ [cal BC 11,826:11,312] (Correal 1982). The third site is Tequendama whose earliest occupation is dated stratigraphically between $12,500 \mathrm{BP}$ and 10,920 $\pm 260 \mathrm{BP}(\mathrm{GrN}-6539)$ [cal BC 11,358:10,193] and contains Holocene faunal remains similar to those found at El Abra II but associated to a different kind of technology called Tequendamiense. The main differences cited between the Tequendamiense and Abriense class are the use of allochthonous materials and the presence of scrapers, thinning flakes and a projectile point fragment in the former (Correal and Van der Hammen 1977:34). These data suggest that human entry into the Sabana de Bogotá occurred during the Guantiva Interstadial, a period of time that displayed a slight rise in temperatures allowing a faunal-rich Andean forest development (Correal 1986; Correal and Van der Hammen 1977).

Correal defined the early evidences in the Sabana de Bogota within the Abriense and Tequendamiense industries (Correal and Van der Hammen 1977:28). Abriense class is made by direct percussion to extract flakes without platform preparation using mostly local lidite. Flakes are then retouched with direct percussion and were, therefore considered in the edge-trimmed tool tradition (Figure 2) (Correal 1986; Correal and Van der Hammen 1977:167). 


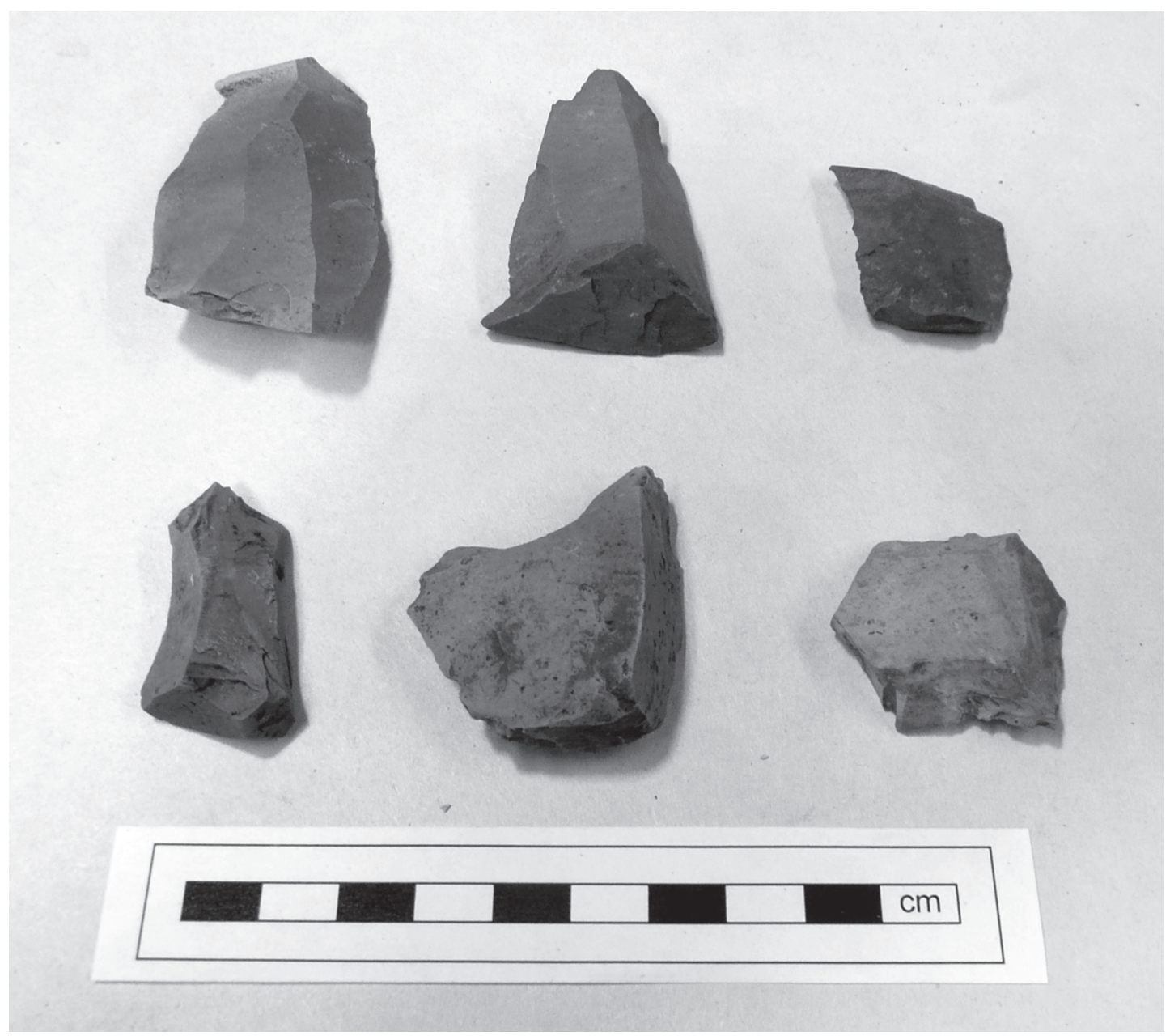

Figura 2. Sabana Unifacial tools Abriense class.

Artefactos unifaciales de la clase Abriense, Sabana de Bogotá.

Within this class, most of the tools were categorized as triangular flakes (the predominant type), side and end scrapers and knives (Van der Hammen, Correal and Lerman 1966, 1969).

Tequendamiense class, on the other hand, is characterized by a finer technique than Abriense, which allowed the manufacture of more elaborate tools, made on high quality chert brought from Middle Magdalena Valley in fact the Tequendamiense artifacts may have been brought to the Sabana de Bogota site from Middle Magdalena. Tequendamiense tool making technique involved platform preparation allowing the production of highly standardized prismatic flakes and blades (Correal 1986; Correal and Van der Hammen 1977:168). Some tools show edge retouch and three bifaces and a plane-convex scraper display pressure flaking thinning (Correal and Van der Hammen 1977:167). Technologically, the bifacial thinning is the key difference between the Tequendamiense and the Abriense class. Chronologically Tequendamiense artifacts date between $\sim 11,000$ and $\sim 10,000 \mathrm{BP}$, roughly coinciding with the Abra interstadial (Correal 1986).

There is reason to question the differentiation made between the two class thirty years ago, due to the spatial proximity and chronological contemporaneity. As Correal himself has argued, it is likely that both industries belong to the same human groups that inhabited the Sabana de Bogota towards the end of the Pleistocene (Correal 1986). The initial classification of both assemblages followed a morpho functional approach despite the 
efforts to do use-wear analysis (Correal 1981). Both industries were associated with the faunal remains recovered from the archaeological sites. This linkage forged the idea that both industries -Abriense and Tequendamiense- were strongly related to hunting and butchering activities. However towards the end of the 1990s Nieuwenhuis (2002) challenged that hypothesis with the results of her use-wear analysis that employed high power magnification, and suggested that Abriense and Tequendamiense were technologies with wide spectrum uses that included plant processing (Nieuwenhuis 2002:66).

The Middle Valley of Magdalena River (from now on Middle Magdalena' (Figure 1) is the other Colombian region with lithic assemblages that belong chronologically to the Late Pleistocene. It is located in a large fluvial valley in the middle of the country ranging from 150 to $450 \mathrm{~m}$ asl within the Tropical Moist Forest biome (López 1989, 1999:31-32). In this region the chronological sequence is more varied than in the Bogota Sabana. There is a site with lithic specimens (eight unifacial tools in a clay matrix) called Pubenza that has been dated to $16,400 \pm 420 \mathrm{BP}(\mathrm{GrN}-$ 19857) [cal BC 18,830:16,869] associated with mastodon (Haplomastodon waringi) and other animal remains within a dated stratified sequence, dated between 16,550 $\pm 150 \mathrm{BP}(\mathrm{GrN}-662)$ [cal BC $18,403: 17,629]$ and $13,280 \pm 110 \mathrm{BP}(\mathrm{GrN}-20101)$ [cal BC 14,333: 13,687] (Correal 1993; Van der Hammen and Correal 2001). Without entering on the debate that this site has generated, we can say that this early date contributes to the evidence that humans entered South America during the Late Pleistocene far earlier than the Clovis First model suggested, a model now thoroughly discredited.

Leaving Pubenza aside, the rest of the archaeological evidence for early human occupation in the Middle Magdalena Valley dates between $\sim 10,400$ and $\sim 10,000 \mathrm{BP}$, with clear continuity into the early Holocene (López 1999:65). The study of lithic technology in the Middle Magdalena brought about significant theoretical and methodological changes for Colombian archaeology. One of the major ones regarding classification was the inclusion of the debitage within the analysis enabling the reconstruction of reduction sequences for tools and determine activity areas within sites. In this sense, lithic analysis was focused on artifact classification following technological and functional criteria.
In terms of debitage thinning flakes to manufacture bifacial tools are the most important type. In terms of tools López (1999:86) determined two main reduction sequences: 1) bifacial, and 2) unifacial. Bifacial tools are represented by stemmed triangular projectile points, manufactured on chert and white quartz (Figure 3a) (López 1990:90). Unifacial tools are composed mainly of expedient tools and plane-convex scrapers manufactured on chert (Figure 3b) (López 1990:90). Most of the plane-convex scrappers and projectile points were surface collected. Only two scrapers from the Palestina site $(10,230 \pm 80$ BP) [cal BC 10,293: 9,670] (López 1998), one from the Torre 46 site $(10,400 \pm 40$ BP) (Beta-70040) [cal BC 10,473: 10,125] (López 2008), and a quartz point from San Juan de Bedout site (10,350 \pm 90 BP) (Beta-40852) [cal BC 10,581: 9,980] (López 1998) have associated dates. Thinning flakes found on the Yondó site dated between 10,300 \pm 70 BP (Beta-123566) [cal BC 10,448:9,872] and 10,260 \pm 70 BP (Beta-123565) [cal BC 10,435: 9,806] suggest the manufacture of bifacial tools at the end of the Pleistocene in the Middle Magdalena (López 1999:71).

Use-wear analysis has suggested that projectile points were used for fishing and hunting, as well as for butchering and processing the skins of captured animals (Nieuwenhuiss 2002:105). Scrapers have been associated with hide processing (Nieuwenhuiss 2002:89). In some unspecified tools Nieuwenhuiss $(2002: 92,96)$ reports the recovery of vegetal fibers, phytoliths, and starch grains. These analyses suggest a wide spectrum economy adapted to a riverine environment (Otero and Santos 2002), and weaken the argument of the existence of a tradition of specialized megafauna hunters and gatherers in the Middle Magdalena, suggested as a last refuge for these animals at the end of the Pleistocene (López 1999:101).

Along the Magdalena River Valley there are several surface collections of the same lithic tradition, which suggests the importance of the river as a corridor for human expansion in the Northern Andes (López 1999:108).

\section{The Early Holocene: Lithic Technology Diversification}

At the beginning of the Holocene ( 10,000 BP) significant environmental changes affected the flora and fauna of northern South America (Marchant et al. 

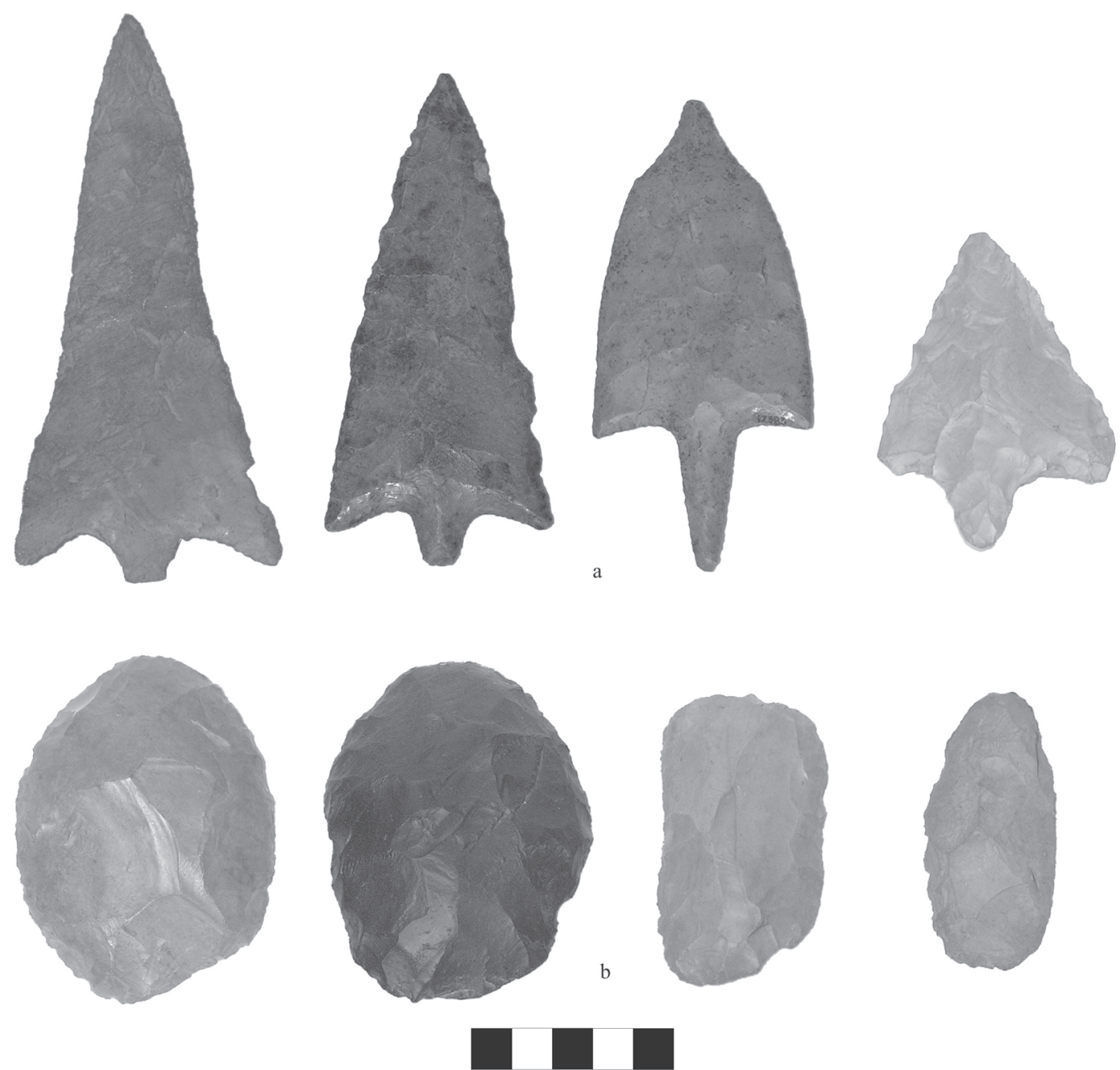

Figure 3. Middle Magdalena: (a) triangular projectile points; (b) plane-convex scrapers. Magdalena Medio: (a) puntas de proyectil triangulares; (b) raspadores plano convexos.

2002; Piperno and Pearsall 1998; Van der Hammen 1992). During this time there is a notable growth in number of archaeological sites in the Andean zone as well as adaptive adjustments to the new environmental conditions (Aceituno et al. 2013; Ranere and López 2007). Archaeobotanical evidence suggests that there is an increase in the processing of plants (likely for consumption), alteration of forest ecosystems, as well as the first evidences of plant cultivation (Aceituno et al. 2012; Aceituno and Castillo 2005; Gnecco 2000; Morcote et al. 1998; Santos 2008). In terms of lithic technologies there are continuities as well as discontinuities in northern South America.

In the Sabana de Bogota the biggest change is the gradual disappearance of debitage techniques associated with Tequendamiense class at $\sim 10,000 \mathrm{BP}$ and the continuity into the Holocene of the Abriense class (Correal 1986). In the Middle Magdalena the terminal Pleistocene lithic technology continues into the middle Holocene. Generally speaking this has been interpreted as continuity in subsistence strategies for both regions (Correal 1986; Otero and Santos 2002).

Most of the archaeological record from the early Holocene is located within the Western and Central Cordilleras, and an isolated site in the Colombian Amazon basin. In the Cordillera Central, on the Popayan Plateau (Figure 1), two sites -San Isidro and La Elvira- are located at $1,700 \mathrm{~m}$ asl in the premontane humid forest (Gnecco 2000:17). 
Over 70,000 artifacts were recovered from both sites, 1,252 tools are classified as and the rest as debitage (Gnecco 2000:48, 85). The preceramic component of San Isidro has been dated between 10,050 \pm 100 BP (Beta-65878) [cal BC 10,027: 9,310] and 9,530 \pm 100 BP (Beta-65877) [cal BC 9220: 8,632] (Gnecco 2000:48). San Isidro lithic technology is composed of retouched and unretouched unifacial tools, bifacial tools (including stemmed points), grinding tools such as handstones and flat grinding bases, and a single ground stone axe (Gnecco 2000:53).

The Popayan Plateau archaeological investigations were the first ones to analyze the social significance of technology and mobility patterns. Gnecco and Bravo's (1997), analysis of technology based on the operatorie chaine (Leroi Gourhan 1971), technological style (Lechtman 1977), and isocrestic style (Sackett 1982), considered that the bifacial reduction sequences represented socially and idiosyncratically determined methods for tool production. The mobility patterns were correlated with artifact curation levels; it's the low levels recorded indicated that there was low mobility (Gnecco 2000:123).

Research conducted in the Popayan Plateau also pioneered in use-wear and residue analysis within Colombia. The use-wear analysis attempted to use low and high power magnification, aiming to observe micro fractures on the working edges (low power) and striations and polish on surfaces (high power). However, the study was only able to identify traces of micro-fractures and polish on artefacts from San Isidro (Gnecco 2000:161-165). Residue analysis was performed on a grinding tool, identifying phytoliths and starch grains, suggesting the importance of plants for the early inhabitants of the Popayan Plateau (Piperno and Pearsall 1998:200).

North of the Popayan Plateau following the Cauca River, in the region denominated Middle Cauca (Cordillera Central), where an important number of archaeological sites are located (over 20 ) in the moist premontane forest at about $\sim 1,600 \mathrm{~m}$ asl (Aceituno and Loaiza 2007:29) (Figure 1). Early Holocene components from all these sites are dated between 10,120 $\pm 70 \mathrm{BP}$ (Ua-24497) [cal BC 10,078: 9,447] (Aceituno y Loaiza 2007:44) and 4,180 70 BP (Beta-95063) [cal BC 2,905: 2,577] (INTEGRAL 1997) with many dates in between. Lithic technology is mainly composed of three main groups: (1) flint-knapped artifacts, (2) axes/ waisted-hoes, (3) grinding tools.
Flint-knapped artifacts include cores, debitage, and flaked tools. Flake tools are obtained by direct percussion and predominately unretouched with different working edge angles, related to cutting, shaving and scraping activities (Figure 4a). These flake tools are manufactured on readily available local raw materials such as basalts, andesites, and dacites, among others (Aceituno and Loaiza 2007:57-65). A special case is the lithic workshop of El Antojo, where thousands of flakes $(\sim 4,000)$ as well as cores and a bifacial preform, were recovered (Aceituno and Loaiza 2007:77; INTEGRAL 1997). Axes/waisted-hoes were manufactured on local volcanic rocks, by direct percussion and in some cases grinding the edges. Most of them have waists on the basal end for hafting (Figure 4b). Grinding tools are composed of handstones and grinding bases (Figure 5) very much like the ones find in other areas close to Colombia, like Panama and Ecuador (e.g. Cooke and Ranere 1992; Castillo and Aceituno 2006; Cardona et al. 2007; Ranere 2008; Stothert 1985).

The Middle Cauca lithic technology is mostly oriented towards the exploitation of plant resources. Phytoliths and starch grains recovered from highlight the importance of plants in the economy of early Holocene groups in this Andean region. Moreover, the recovery of starch grains from axes/waisted-hoes, suggest that they were used to process tubers and rhizomes and not so much as axes (Aceituno and Loaiza 2007). The nature of the Middle Cauca's lithic technology -low diversity, absence of some phases of the operatorie chaine, and presence of curation (in some axes/waisted-hoes)- has been interpreted as evidences of residential mobility (Aceituno and Loaiza 2007:79).

North of the Middle Cauca, in the Middle Porce River Basin (from now on Middle Porce) (Cordillera Central) (Figure 1) at the intersection of the humid tropical forest and humid premontane forest (between $\sim 850$ and 1,180 masl) are six sites dated between 10,260 \pm 50 BP (Beta-205293) [cal BC 10,225: 9,818] and 3,650 \pm 40 BP (Beta-205297) [cal BC 2,139: 1,917] (Castillo and Aceituno 2006; Cardona et al. 2007:580; Otero et al. 2006:409).

Middle Porce lithic technology is similar to that of the Middle Cauca and it is composed of three main groups: (a) axes/hoes (Figure 6a), (b) grinding tools, and (c) flint-knapped tools. This last group is the largest one and includes four bifacial projectile points (Figure $6 \mathrm{~b}$ ), and many other types 

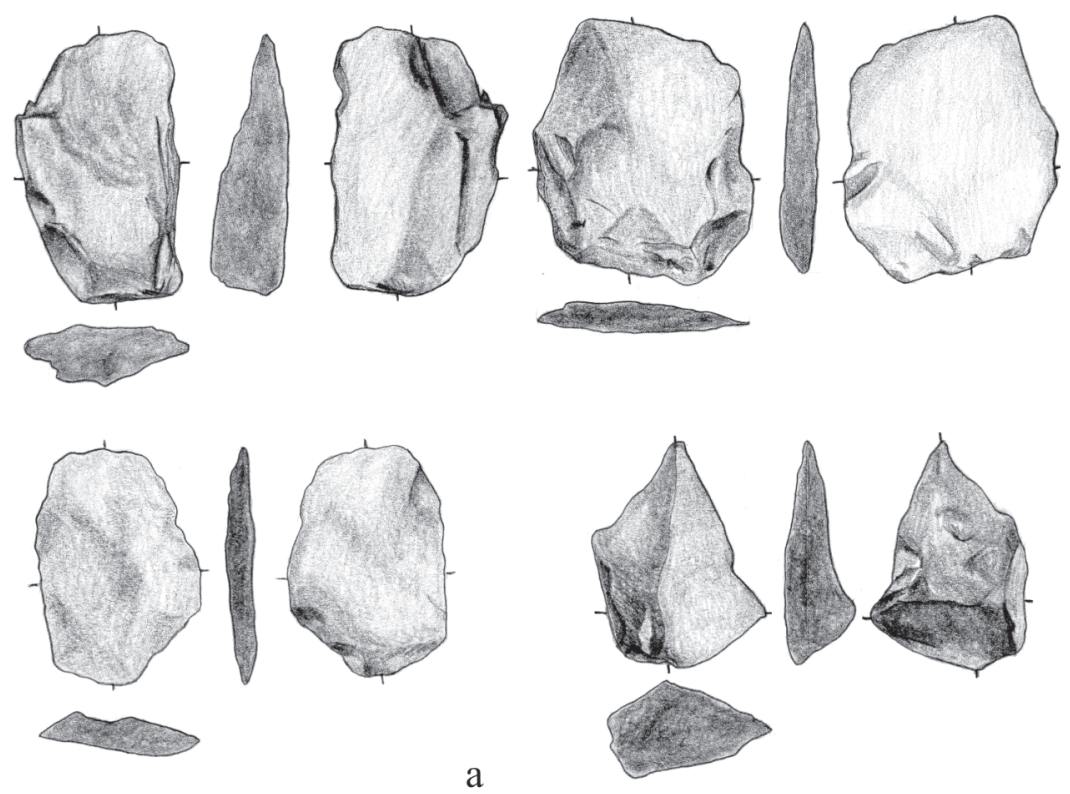

a
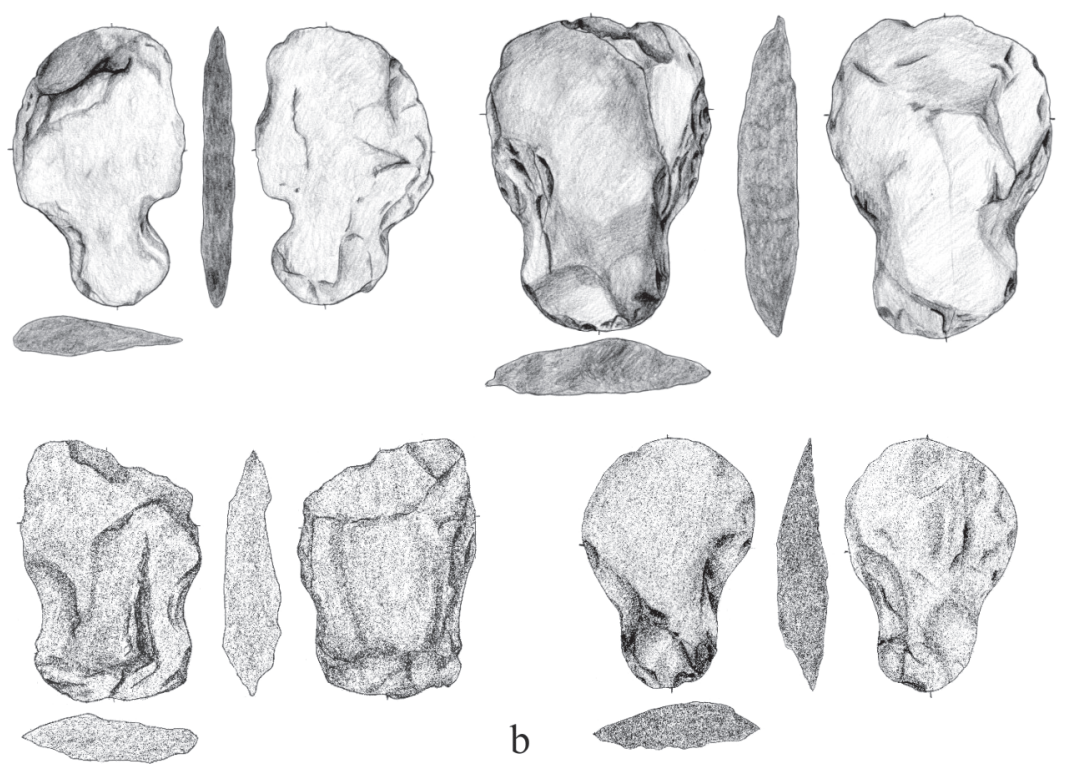

Figure 4. Middle Cauca: (a) unifacial tools; (b) axes/waisted-hoes.

Cauca Medio: (a) artefactos unifaciales; (b) hachas/azadas con escotadura.

(Aceituno 2001) such as cutting tools, scrapers, burins, perforators, and wedges. These tools are manufactured mostly on local white quartz and a few on foreign chert and lidite (Aceituno 2001).

In terms of economy, the lithic technology from Middle Porce has been identified with a broad spectrum strategy that includes plant gathering and cultivation as well as hunting. Both axes/hoes and grinding tools are closely associated to plant exploitation, supported by the recovery of phytoliths and starch grains from these types of artifacts (Castillo and Aceituno 2006; Otero and Santos 2012:198-199). 

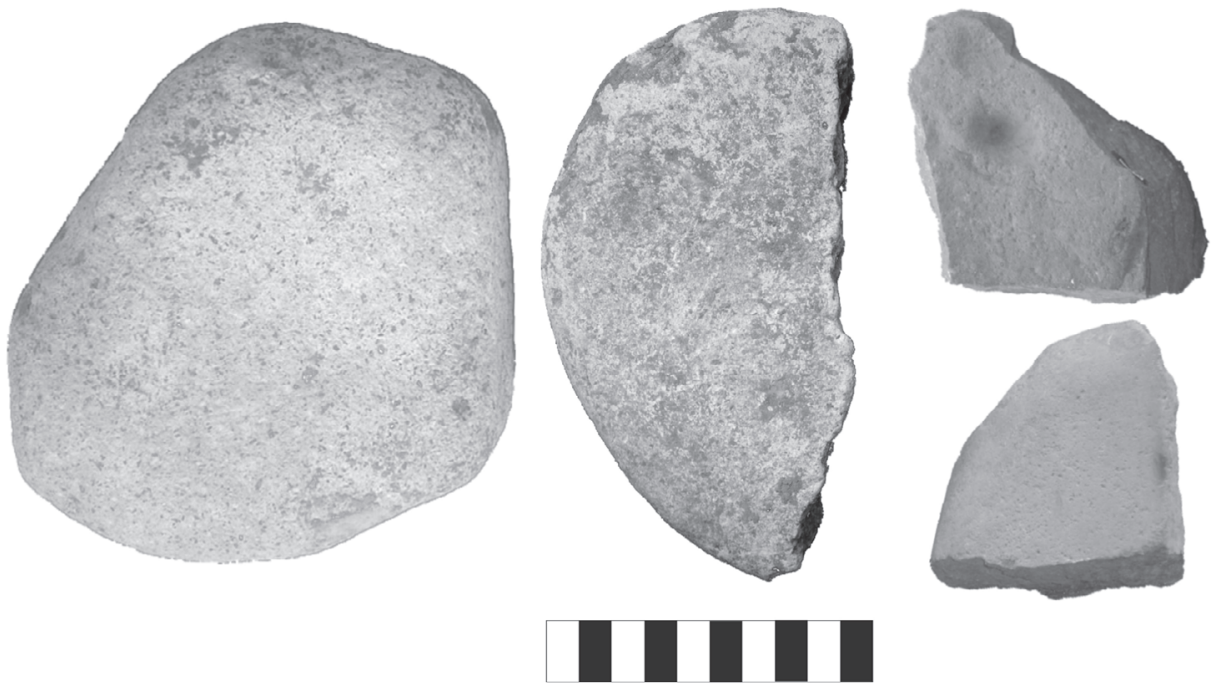

Figure 5. Middle Cauca: Grinding bases.

Cauca Medio: bases de molienda.
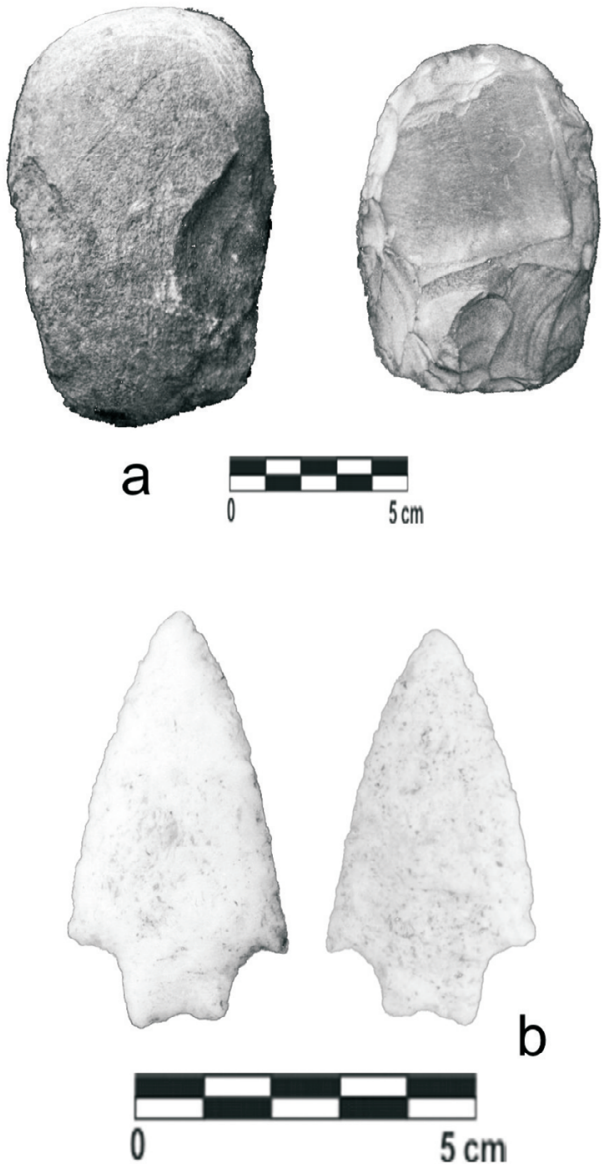

Figure 6. Middle Porce: (a) axes; (b) bifacial projectile point. Porce Medio: (a) hachas; (b) punta de proyectil bifacial.
Based on the presence of all the phases of the operatorie chaine it has been argued that some sites (021 and 045) are residential camps. The predominance of expedient tools along with the identification of curated tools has been interpreted as an indicator of low residential mobility (Aceituno 2001).

In the upper Porce River Basin, about $100 \mathrm{~km}$ south of Middle Porce (Figure 1) there are two sites with similar technology to what has been previously described, named La Morena site dated between 10,060 \pm 60 BP (Beta-245566) [cal BC 9,881: 9366] and 4,170 \pm 50 BP (Beta-245565) [cal BC 2,890:2,619] (Santos 2010: 25-29) and La Blanquita site dated 7,720 \pm 50 BP (Beta-162328) [cal BC 6,640: 6,468] (Botero 2008). In this same region but in a different site two chert stemmed projectile points were recovered on the surface, and have been associated with the Middle Magdalena tradition, suggesting relations between the Cordillera Central and the Middle Magdalena (López 1999:107).

In the Calima River Basin (Figure 1) two sites have been dated 9,670 \pm 100 BP (Beta-23476) [cal BC 9,291:8,782] (Sauzalito site) and 4,090 \pm 90 BP (Beta-16839) [cal BC 2,895: 2,459] (El Pital site), both located in the premontane humid forest. Calima lithic technology is characterized by unifacial flakes, hammer stones, anvils, handstones, and axes/hoes (with hafting preparations on the basal end) (Herrera et al. 1988; Salgado 1988-1990). During the early and 
middle Holocene, the Calima and Middle Magdalena regions share the same lithic technology.

Peña Roja site is located in the Colombian Amazon region (Figure 1) and has been dated between 9,250 \pm 140 BP (Beta-52964) [cal BC 8,849: 8,211 ] and 8,090 \pm 60 BP (UCR-3419) [cal BC 7,301: 6,823] (Mora 2003: 92; Piperno and Pearsall 1998:204). The lithic assemblage is composed of unifacial tools such as scrapers, shavers, small flakes, choppers, wedges, grinding bases and manos, handstones and anvils (Cavelier et al. 1995). This diverse lithic technology has been associated to a wide spectrum economy that includes hunting for tropical rain forest fauna, as well as plant collection, especially palm fruits as indicated by the thousands of macrobotanical remains of several palm genera (Oenocarpus, Mauritia y Astrocaryum), as well as other wild fruits (Morcote et al. 1998). In Peña Roja archaeologists also recovered phytoliths (Piperno and Pearsall 1998:204-205).

\section{Discussion}

The methodological and theoretical approaches taken by Correal and his team set the initial direction of lithic technology studies in Colombia (López 1999:30-31). The definition of Abriense and Tequendamiense lithic industries was the first attempt at lithic classification and typology and served as a working model for lithic analysis in Colombia. Abriense, for example, has been used as a classification model for any simple lithic technology disregarding time and place within Colombia. This usage has occurred despite the fact that Abriense was initially conceived as a referent for an archaeological culture, in the historical particularism sense, and not as a global typological referent based on technofunctional criteria.

By the end of 1980s and the beginning of the 1990s an important change happened on lithic technology analysis. Salgado $(1988,1990)$ based on the Calima assemblages, suggested important differences with the Sabana de Bogota lithic technologies, and connected the tools with the exploitation of forest resources emphasizing the role of plants amongst the early Calima inhabitants. López (1991, 1999) contributed an important step by including debitage as an indicator of reduction sequences. That said, the work of Gnecco and his team (Gnecco 2000; Gnecco and Bravo 1997) was as important as Correal's in his time, because it introduced the concept of operatorie chaine and applied procesualists analysis to expand upon the simple classificatory focus that had prevailed thus far.

The current tendency in lithic technology analysis has evolved from a classificatory focus (very important to name and describe archaeological cultures) to an eclectic focus that mixes European and North American theoretical and methodological traditions, aiming to relate lithic assemblages with behavioral aspects, such as manufacture, use, discard, and social production of artifacts, among others.

Finally it is important to mention that there are important fields that remain pretty much unexplored, such as use-wear and residue analysis that could aid archaeologists in understanding important cultural aspects and reclaim the importance of lithic analysis that it deserves. There have been some studies on residue analysis that evaluate microbotanical remains (e.g. Aceituno et al. 2001; Aceituno and Lalinde 2011; Morcote 2008; Piperno and Pearsall 1998) and that have shown the importance that lithc technology had on plant processing. This research has allowed professional archaeologists to suggest hypotheses about adaptive strategies and resource management. The application of novel techniques and theoretical approaches is key to fostering the advancement of knowledge of early hunters and gathers in northwest South America.

Acknowledgements: To Carlos E. López who authorized us to use figure 3 . To Nicolás Loaiza who edited the figure 1 . To University of Antioquia who supported this work. Thanks to anonymous reviewers for theirs relevant comments; however, all responsibility is our own.

\section{References Cited}

Aceituno, F.J. 2001. Ocupaciones Tempranas del Bosque Tropical Subandino en la Cordillera Centro-occidental de Colombia. Disertación Doctoral. Facultad de Geografía e Historia, Universidad Complutense de Madrid, España.
Aceituno. F.J., J.J. Terraseras, A. Jaramillo and L. Vélez 2001. Identificación de plantas alimenticias en el Cauca Medio durante el Holoceno Temprano y Medio. Boletín de Antropología 15(32):51-72 
Aceituno, F.J. and N. Loaiza 2007. Domesticación del Bosque en el Cauca Medio Colombiano entre el Pleistoceno Final y el Holoceno Medio. BAR International Series 1654, Archaeopress, Oxford.

Aceituno, F.J. and N. Castillo 2005. Strategies of mobility in the Middle Range of Colombia. Before Farming 2005/2. article 2

Aceituno, F.J. and V. Lalinde 2011. Residuos de almidones y el uso de plantas durante el Holoceno Medio en el Cauca Medio (Colombia). Caldasia 33:1-20.

Aceituno, F.J., N. Loaiza., M.E. Delgado and G. Barrientos 2013. The Initial Human Settlement of Northwest South America during the Pleistocene/Holocene Transition: Synthesis and Perspectives. Quaternary International 301:23-33.

Aceituno, F.J. and S. Rojas 2012. Del Paleolítico al Formativo: 10.000 años de historia de la tecnología lítica en Colombia. Boletín de Antropología 26:124-156.

Anderson, D. and Ch. Gillam 2000. Paleoindian colonization of the Americas: implications from an examination of physiography, demography and artefact distribution. American Antiquity 65:43-66.

Castillo, N. and F.J. Aceituno 2006. El bosque domesticado, el bosque cultivado: un proceso milenario en el valle medio del Río Porce en el Noroccidente colombiano. Latin American Antiquity 17:561-578.

Botero, S. 2008. Ocupaciones tempranas en el Valle del Aburrá. Sitio la Blanquita. In Ecología Histórica: Interacciones Sociedad Ambiente a Distintas Escalas Socio Temporales, edited by C. López and G. Ospina, pp. 80-83. Universidad Tecnológica de Pereira, Universidad del Cauca and Sociedad Colombiana de Arqueología, Pereira.

Cardona, L.C., L.E. Nieto and J. Pino 2007. Del Arcaico a la Colonia. Construcción del paisaje y cambio social en el Porce Medio. Informe final. Universidad de Antioquia and Empresas Públicas de Medellín, Medellín.

Cavelier, I., C. Rodríguez, L.F. Herrera, G. Morcote and S. Mora 1995. No solo de la caza vive el hombre ocupación del bosque amazónico, Holoceno Temprano. In Ambito y Ocupaciones Tempranas de la América Tropical, edited by I. Cavelier and S. Mora, pp. 27-44. Fundación Erigaie, Instituto Colombiano de Antropología, Bogotá.

Cooke, R. and A. Ranere 1992. Prehistoric human adaptation to seasonally dry forests of Panama. World Archaeology 24:114-133.

Correal, G. 1981. Evidencias Culturales y Megafauna Pleistocénica en Colombia. Fundación de Investigaciones Arqueológicas Nacionales. Banco de la República, Bogotá.

Correal, G. 1982. Restos de megafauna en la Sabana de Bogotá. Caldasia XIII (64):487-547.

Correal, G. 1986. Apuntes sobre el medio ambiente pleistocénico y el hombre prehistórico en Colombia. In New Evidence for the Pleistocene Peopling of the Americas, edited by A. Bryan, pp. 115131. Center for Study of Early Man, University of Maine, Orono.

Correal, G. 1993. Nuevas evidencias culturales pleistocénicas y megafauna en Colombia. Boletín de Arqueología 8:3-13.

Correal, G. and T. Van der Hammen 1977. Investigaciones Arqueológicas en los Abrigos Rocosos del Tequendama. Biblioteca Banco Popular, Bogotá.
Dillehay, T. 2000. The Settlement of the Americas. Basic Books, New York.

Fiedel, S.J. 2000. The peopling of the new world: present evidence, new theories, and future directions. Journal of Archaeological Research 8:39-103.

Gnecco, C. 2000. Ocupación Temprana de Bosques Tropicales de Montaña. Universidad del Cauca, Popayán.

Gnecco, C. and M. Bravo 1997. Análisis sintáctico de la tecnología de reducción bifacial en San Isidro, un sitio de cazadores-recolectores del holoceno temprano. Boletín del Museo del Oro 37:77-96.

Herrera, L., W. Bray, M. Cardale de Shcrimpff and P. Botero 1988. Nuevas fechas de radiocarbono para el precerámico en la Cordillera Occidental de Colombia. Presented at the 46th International Congress of Americanists, Amsterdam.

Hurt, W., T. Van der Hammen and G. Correal 1972. Preceramic sequences in the El Abra rock-shelters, Colombia. Science 175:1106.

INTEGRAL 1997. Arqueología de Rescate: vía alterna de la troncal de Occidente río Campoalegre-Estadio Santa Rosa de Cabal. Informe Final. INTEGRAL S.A., Ministerio de Transporte and Instituto Nacional de Vías, Medellín. Unpublished manuscript.

Lechtman, H. 1977. Style in technology: Some early thoughts. In Material Culture: Styles, Organization and Dynamics of Technology, edited by H. Lechtman and R.S. Merril, pp. 2-15. West Publishing Company, St Paul.

Leroi-Gourhan, A. 1971. El Gesto y la Palabra. Universidad Central de Venezuela, Caracas.

López, C. 1998. Evidence of late Pleistocene/early Holocene occupations in the tropical lowlands of the Middle Magdalena valley. In Recent Advances in the Archaeology of the Northern Andes in Memory of Gerardo Reichel Dolmatoff, edited by A. Oyuela-Caycedo and J.S. Raymond, pp. 1-19. The Institute of Archaeology, University of California, Los Angeles.

López, C. 1991. Investigaciones Arqueológicas en el Magdalena Medio, Cuenca del Río Carare (Departamento de Santander). Fundación de Investigaciones Arqueológicas Nacionales. Banco de la República, Bogotá.

López, C. 1999. Ocupaciones Tempranas en las Tierras Bajas Tropicales del Valle Medio del Río Magdalena: sitio 05-Yon-002 Yondó-Antioquia. Fundación de Investigaciones Arqueológicas Nacionales. Banco de la República, Bogotá.

López, C. 2008. Landscape Development and the Evidence for Early Human Occupation in the Inter-Andean Tropical Lowlands of the Magdalena River, Colombia. Syllaba Press, Miami.

Lynch, T. 1990. ¿Glacial-age man in South America? A critical review. American Antiquity 55:12-36.

Marchant, R., H. Behling, J.C. Berrío, A. Cleef, J. Duivenvoorden, H. Hooghiemstra, P. Kuhry, B. Melief, E. Schreve-Brinkman, B. van Geel, T. Van der Hammen, G. Van Reenen and M. Wille 2002. Pollen-based biome reconstructions for Colombia at 3000, 6000, 9000, 12000, 15000 and $18000{ }^{14} \mathrm{C}$ year ago: Late Quaternary tropical vegetation dynamics. Journal of Quaternary Science 17:113-129.

Mora, S. 2003. Early Inhabitants of the Amazonian Tropical Rain Forest a study of Humans and Environmental Dynamics. Habitantes Tempranos de la Selva Tropical Lluviosa Amazónica un Estudio de 
las Dinámicas Humanas y Ambientales. Universidad Nacional de Colombia-Sede Leticia-, Instituto Amazónico de InvestigacionesIMANI-, University of Pittsburgh, Department of Anthropology, Latin American Archaeology Reports No. 3, Pittsburgh.

Morcote, G. 2008. Antiguos Habitantes en Ríos de Aguas Negras. Ecosistemas y Cultivos en el Interfluvio Amazonas-Putumayo Colombia-Brasil. Instituto de Ciencias Naturales. Universidad Nacional de Colombia, Bogotá.

Morcote, G., G. Cabrera, D. Mahecha, C. Franky and I. Cavelier 1998. Las palmas entre los grupos cazadores-recolectores de la Amazonía colombiana. Caldasia 20:57-74

Nieuwenhuis, C.J. 2002. Traces on Tropical Tools: A Functional Study of Chert Artifacts from Preceramic Sites in Colombia. Doctoral Dissertation, Leiden University, Archaeological Studies, Ámsterdam.

Otero, H. and G. Santos 2002. Aprovechamiento de recursos y estrategias de movilidad de los grupos cazadores-recolectores holocénicos del valle medio del Magdalena, Colombia. Boletín de Antropología 16:100-134.

Otero, H. and G. Santos 2006. Las ocupaciones prehispánicas del cañón del Río Porce. Prospección rescate y monitoreo Arqueológico. Proyecto hidroeléctrico Porce III - Obras de Infraestructura. Universidad de Antioquia-Empresas Públicas de Medellín, Medellín. Unpublished manuscript.

Otero, H. and G. Santos 2012. Porce III proyecto hidroeléctrico estudios de arqueología preventiva. Dinámica de cambio en las sociedades prehispánicas de la cuenca baja del río Porce. Empresas Públicas de Medellín, Medellín.

Piperno, D. and D. Pearsall 1998. The Origins of Agriculture in The Lowland Neotropics Academic Press, San Diego.

Ranere, T. 2008. Lower Central America. In Encyclopedia of Archaeology, edited by D. Pearsall vol 1, pp. 192-209. Academic Press, New York.

Ranere, A. and C.E. López 2007. Cultural diversity in Late Pleistocene/Early Holocene populations in northwest South America and lower Central America. International Journal of South American Archaeology 1:25-31.
Reimer, P.J., E. Bard, A. Bayliss, J.W. Beck, P.G. Blackwell, C. Bronk Ramsey, C.E. Buck, H. Cheng, R.L. Edwards, M. Friedrich, P.M. Grootes, T.P. Guilderson, H. Haflidason, I. Hajdas, C. Hatte, T.J. Heaton, D.L. Hoffmann, A.G. Hogg, K.A. Hughen, K.F. Kaiser, B. Kromer, S. Manning, M. Niu, R.W. Reimer, D.A. Richards, E.M. Scott, J.R. Southon, R.A. Staff, C.S. Turney and J. van der Plicht 2013. IntCal13 and MARINE13 radiocarbon age calibration curves 0-50000 years calBP. Radiocarbon 55:1869-1887.

Sackett, J. 1982. Approaches to style in lithic archaeology. Journal of Anthropological Archaeology 1:59-112.

Salgado, H. 1988-1990. Asentamientos precerámicos en el alto medio río Calima, Cordillera Occidental, Colombia. Cespedesia 57-58:139-162. Cali.

Santos, G. 2008. Cazadores-Recolectores y horticultores del Holoceno temprano y medio en la cuenca baja del Porce. In Ecología histórica: Interacciones Sociedad Ambiente a Distintas Escalas Socio Temporales, edited by C. López and G. Ospina, pp. 74-77. Universidad Tecnológica de Pereira, Universidad del Cauca and Sociedad Colombiana de Arqueología, Pereira.

Santos, G. 2010. Diez. Mil Años de Ocupaciones Humanas en Envigado (Antioquia). El Sitio La Morena. Alcaldía de Envigado, Secretaría de Educación para la Cultura, Envigado.

Stothert, K. 1985. The preceramic Las Vegas culture of coastal Ecuador. American Antiquity 50:613-637.

Van der Hammen, T. 1992. Historia, Ecología y Vegetación. Corporación Colombiana para la Amazonia Araraucara, Bogotá.

Van der Hammen, T. and G. Correal 2001. Mastodontes en un humedal pleistocénico en el valle del Magdalena (Colombia) con evidencias de la presencia del hombre en el pleniglacial. Boletín de Arqueología 16:4-36. Bogotá.

Van der Hammen, T., G. Correal and J.C. Lerman 1966-1969. Artefactos líticos de abrigos rocosos en: El Abra, Colombia. Revista Colombiana de Antropología 14:11-46.

Waguespack, N. 2007. Why we are still arguing about the Pleistocene occupation of the Americas. Evolutionary Anthropology 16:63-74.

1 All calibrated results have 2 sigma calibration with program Calib Rev 7.0.0 (data set used: intCal3.14c) from Reimer et al. 2013 
